\title{
It's Time to Remove the Pump Handle (Again)
}

\author{
Edward Mc Bean ${ }^{1,2 *}$
}

${ }^{1}$ Engineering University of Guelph Research Leadership Chair Professor, Water Security

${ }^{2}$ Former Tier Canada Research Chair, Water Security, University of Guelph, Guelph, Canada

ISSN: 2639-0574

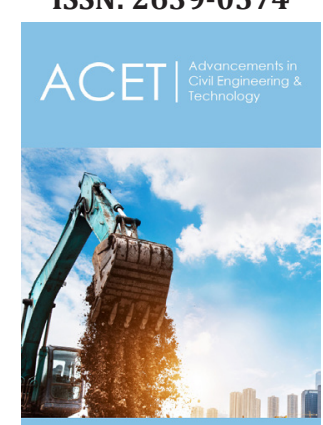

*Corresponding author: Edward Mc Bean, Engineering University of Guelph Research Leadership Chair Professor, Water Security, Canada

Submission: 酶October 05, 2020

Published: 䟧October 22, 2020

Volume 4 - Issue 4

How to cite this article: Edward Mc Bean. It's Time to Remove the Pump Handle (Again). Adv Civil Eng Tech. 4(4) ACET.000591. 2020.

DOI: 10.31031/ACET.2020.04.000591

Copyright@ Edward Mc Bean, This article is distributed under the terms of the Creative Commons Attribution 4.0 International License, which permits unrestricted use and redistribution provided that the original author and source are credited.

\section{Opinion}

In 1854, one of the founders of modern epidemiology, Dr. John Snow, removed the handle from the Broad Street pump, in London, England. This seminal moment was based on Dr. Snow's realization that the cholera plague raging through London was occurring due to people accessing this particular public water well. The public water well had been dug only 3 feet from a cesspit which had become contaminated by the diapers from a baby who had contracted cholera from another source. By removing the handle of the pump, Dr. Snow's action is widely credited as instrumental in ending the outbreak of cholera in London.

Now, consider the situation with COVID 19 in, for example, Zimbabwe. The situation in Zimbabwe as detailed by Cathy Buckle (http://cathybuckle.co.zw) describes Ms. Buckle venturing out very early on Day 5 of Zimbabwe's 21day Coronavirus lockdown. She realized people who live hand-to-mouth and eke out a living selling fruits and vegetables from roadside stalls would be encountering dry taps, and hence, were out looking for water. Cathy described passing a man pushing a wheelbarrow with empty yellow water containers, heading towards a public borehole. Fourteen people were already there ahead of him, anxiously standing in line at the borehole waiting for their turn to use the hand pump and fill their containers with water. This, she describes is coping with Coronavirus 'Zimbabwe style'.

With the frighteningly easy transmissibility of the COVID-19 virus, we must 'remove the pump handle for wells' such as the ones described in Ms. Buckle's article, and replace the handles with a technology that will pump water but does not facilitate the incredibly easy transmissibility of such a virulent illness from one user, to the next. But can we, as civil engineers, stop at 'just removing the pump handle'? Both to help protect the people in the developing world but also, to protect what will become subsequent waves of COVID-19 back to the developed world from the so-called 'Global South' countries, we cannot stop at 'just removing the pump handle'. We, in the developed world, must also contribute toward finding solutions to the many other issues, to interfere with the 'exploding' impacts of the virus. Examples of activities that civil engineers may be able to provide include:

A. Help design transit services and operations, including entries and exits, to maximize self-isolation opportunities for travelers/passengers.

B. Identify options for transportation and traffic planning of essential commodities (supply chain) to various parts of a country when a lockdown takes place.

C. People can't protect themselves from the invisible virus when they have no soap and water. Develop improved technologies to facilitate construction of sites where people can find ways to disinfect their hands and faces.

D. Perhaps we can design better waterpoints allowing community member access locations for securing their needed water, while avoiding any opportunities for touching spigots.

E. Is there potential to have more reliable boreholes to avoid entry of ambient surface contamination from entering around the borehole. 
F. Buildings are not designed to be shut down for long periods; the result of long shutdowns may be excessive amounts of heavy metals and pathogens concentration in water in pipes. Impacts of pandemic on buildings are potentially very important. Bacteria that do really well when there is no oxygen in the water in the pipes may outcompete those that need oxygen. Guidelines to facilitate the recovery of their buildings are needed.

G. Refugee camps, filled far beyond capacity, are not providing safe and self-isolated access to water supplies. Fear of COVID-19 disease in the largest refugee camp in the world, Kutupalong Bangladesh, is home to Rohingyas fleeing persecution in Myanmar, with a million in an area which could safely isolate at most 700 persons. Improved technologies for handling solid wastes and wastewaters rampant with the COVID virus won't solve the problem, but there must be ways to lessen the transmissibility of the virus.

H. Find strategies and technologies to set up efficient relief camps for immigrants stuck at different locations

I. Design better systems to provide beds and enclosures that can be mobilized, and easily re-located, to facilitate operational environments for emergency but short-term medical care facilities as the virus spreads from one location to another

J. As we learn more about the COVID-19 virus, it is now apparent that 'sleepers', meaning people carrying the virus but who have no evidence of infection are widespread. Develop AI models to Identify sleepers with no confirmation of illness

K. Healthcare systems in the Global South will be overwhelmed by virus caseloads. Design of better but inexpensive healthcare protection devices so lacking in essential respects, would benefit from better designs, and other dimensions to facilitate better re-use as well being more protective. Engineers need to be looking at better designs and disinfection practices (e.g. to improve the sponge rubber that cause major irritants as well as to allow more multiple uses)

L. We need to design and implement construction practices that will maximize spatial distancing between on-site workers. Are there ways to decrease the time on site of workers?

M. We need to develop better Artificial Intelligence and infectivity models to facilitate focus, in particular, on ways to protect people with compromised immune systems weakened by measles, tuberculosis, malnutrition, AIDS, etc. as these are the people most susceptible to COVID-19.

$\mathrm{N}$. If we identify a virus-free area of a city, AI models could be used to identify if occurrences of virus outbreaks are taking place by monitoring the wastewater, as the virus is excreted from infected people in their faeces.

0. Find ways to improve design wastewater handling/ conveyance procedures to interrupt the transmissibility of the COVID-19 virus via wastewater.

P. Carry out surveillance and modelling of the virus load as it flows through city sewer networks and establish relationships with the infection rate in the community which, in turn, would provide public health officials a decision-making tool regarding mitigation measures.

Q. Identify opportunities to allow employees to work from home. This might include fully embracing the implementing of digital software into work-from-home practices.

R. As well as the potential deaths and the illnesses, outcomes of the COVID-19 are going to include jobs lost, businesses destroyed, soaring government debt and capital flight. The economic consequences are going to be enormous, resulting in economic and humanitarian crises. Solutions must be found.

S. People can't maintain self-isolation and separation distances when food and water are desperately needed for their families, and the food-supply chain isn't functional. Are there means to improve the food-supply chain mechanics?

T. And this list needs to continue to grow....

Let us not forget that in today's world, people around the world are interconnected using airplanes, trains, and ships, as examples, over large distances in short periods of time. This is not a time for civil engineers to simply self-isolate themselves and families and hope the problems of COVID-19 go away. Civil engineers have the opportunity to make real contributions in the international domain, and these benefits will help everyone.

Let's not leave people in Zimbabwe and so many other countries, to cope with Coronavirus 'Zimbabwe style'. 